\title{
An Exploration on Stress Management at Motherson Autmotive Technologies \& Engineering Chennai
}

\author{
Magdalene Peter, S. Fabiyola Kavitha, R. K. Renju
}

\begin{abstract}
Stress delivers various side effects which shift as indicated by people, circumstances, and seriousness. These can integrate decomposition as well as discouragement in physical well-being. The board's stress operation is identified as one of the keys in today's community to a pleasant and efficient existence. In spite of the fact that life gives various requests that can demonstrate hard to deal with, stress the executives gives various approaches to oversee uneasiness and keep up by and large prosperity.

Numerous reasonable pressure the board strategies are accessible, some for use by wellbeing professionals and others for self improvement, which may assist a person with reducing pressure, give constructive sentiments of being responsible for one's life and advance general prosperity.

The viability of the distinctive pressure the board procedures can be hard to evaluate, as few of them have gotten noteworthy consideration from specialists. Subsequently, the amount and nature of the evidence for the various processes usually changes. Some are recognized as feasible psychotherapy medicines, while others with less evidence to favor them are regarded as elective therapies. Numerous expert associations exist to advance and give preparing in traditional or elective treatments.
\end{abstract}

\section{INTRODUCTION}

Stress may be defined as "a state of psychological and / or physiological imbalance resulting from the disparity between situational demand and the individual's ability and / or motivation to meet those demands." [1-3]

Stress the executives alludes to the wide range of methods and psychotherapies planned for controlling an individual's degrees of stress particularly endless pressure, more often than not to improve ordinary working $[4,5]$.

In this particular scenario, the word ' stress ' refers only to a concern with notable adverse outcomes, or difficulty in Hans Selye's phrasing, as compared to what he calls estruses, a pressure whose outcomes are helpful or usually favorable $[6,7]$.

Stress creates various indications which differ as per people, circumstances, and seriousness. These may include diminishing physical well-being just as poverty. The board's stress operation is designated as one of the keys in today's

Revised Manuscript Received on July 22, 2019.

Magdalene Peter, Department of Management Studies, Bharath Institute of Higher Education and Research, Chennai, Tamilnadu, India

S. Fabiyola Kavitha, Department of Management Studies, Bharath Institute of Higher Education and Research, Chennai, Tamilnadu, India

R.K. Renju, Department of Management Studies, Bharath Institute of Higher Education and Research, Chennai, Tamilnadu, India community to a happy and fruitful existence. Despite the fact that life gives various requests that can demonstrate hard to deal with, stress the board gives various approaches to oversee nervousness and keep up in general prosperity [8-10].

Numerous useful pressure the executives methods are accessible, some for use by wellbeing specialists and others for self improvement, which may assist a person with reducing pressure, give constructive sentiments of being responsible for one's life and advance general prosperity $[11,12]$.

It can be difficult to assess the adequacy of the varied stress executive processes, as few of them have been critically considered by commentators. Subsequently, the sum and nature of proof for the different strategies shifts generally. Some are acknowledged as powerful medicines for use in psychotherapy, while others with less proof favoring them are viewed as elective treatments [13-16].

\section{FIGURE OUT WHERE THE STRESS IS ARISING FROM}

Intermittently, when we're focused on, it appears to be a major upset stressors showing up from each edge. We begin to feel like we're playing a round of evade ball, dodging and dashing so we don't get smacked by a torrent of balls. We take a protective position, and not a decent one at that [17].

Rather than feeling like we're thrashing everyday, distinguish what we're really worried about. Is it a particular undertaking at work, an up and coming test, a question with our manager, a load of clothing, a battle with our family? $[18,19]$

\section{CONSIDER WHAT WE CAN MANAGE}

While we can not regulate what we are supervisors, what we are in-laws or the economy's acrid situation, we can regulate how we react, how we accomplish job, how we invest in electricity, and what we spend on money.

Take a job enterprise case. If we are concerned about the extension, talk to the chief about it or divide the undertaking into step-wise assignments and due dates [20-22].

\section{MANAGE THE TIME WeLL}

One of many people's greatest stressors is absence of moment. Their list of to-do is expanding while time is flying. How often have we wanted to

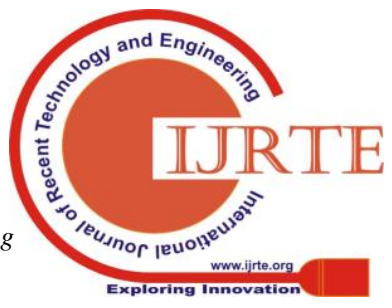


spend more hours in the day or have we heard others lament their absence of moment? But as Laura Vander says in her aptly named novel, 168 Hours, we have more time than we

\section{CReate a toolbox of TeChNiQues}

One pressure contracting procedure won't work for every one of our issues. For example, while profound breathing is useful when we're stuck in rush hour gridlock or hanging at home, it probably won't protect us during a conference [27].

Since stress is perplexing, "What we need is a tool kit that is loaded with strategies that we can fit and decide for the stressor right now," said Richard.

Blonnasuggested asking these questions: "Do mesh with my goals and values? Am I doing things that give my life meaning? Am I doing the right amount of things?" [28].

\section{OBJECTIVES OF THE STUDY}

A study onstress management at "MOTHERSON AUTOMOTIVE TECHNOLOGIES AND ENGINEERING,CHENNAI".

- To understand the employee stress in organization.

- To identify how often the employee facing stress situation at work place.

- To get more information about the employee stress in works satisfaction.

- To know if the employee get time to attend their personal oblige $[29,30]$

\section{NEED FOR THE STUDY}

- To understand the employees stress in MOTHERSON PVT LTD.

- To reduce the employees stress in working hours.

- To relief the stress in employee working hours.

- The need of study in various types of stress in employee facing

\section{SCOPE OF THE STUDY}

- To know about the stress management in every organization.

- To be experienced on how to handle the stress in working hours.

- Employee to change one level to another level based on stress.

- To be reduced on working stress and analysis on strength and weakness about employee.

\section{SIGNIFICANCE OF THE STUDY}

1. The present research distinguishes the ebb and flow level of occupation worry among workers of the chose banks.

2. It discovers the main considerations causing occupation worry among the bank representatives. believe: We have more time than we believe [23-26].

3. The examination additionally discovers the different strategies for lessening employment stress.

4. This investigation causes the top administration to embrace the proper method of decreasing occupation worry of the representatives.

5. The examination is useful for staff supervisors to hold the gifted workforce and execute the conservation system in banks [31]

\section{OBJECTIVES OF THE STUDY}

The principle destinations of the present examination directed in banks are:

- To think about the degree of occupation worry among the workers of chose banks.

- To look at the central point causing occupation worry among the workers of chose banks.

- To recognize the best strategies for lessening occupation stress.

\section{METHOD OF COLLECTION}

- Primary data

The Primary Data are collected by the questionnaire in the employee of the organization.

In this research Primary data collection is used to employees of the banks.

- Secondary data

Secondary data is to be provided the additional information about the stress management.

\section{SAMPLING METHOD}

The sample size is determined by using pilot study of 150 samples. The sample size is

Calculated by,

Sample size $(\mathrm{n})=\mathrm{r}$ z2 / p q/e2

Where $\mathrm{z}=1.96$ and $\mathrm{p}=$ no stress, $\mathrm{q}=$ more stress, $\mathrm{e}=$ neutral $=(1.96) 2(.9)(.1) /(.050) 2$

$\mathrm{N}=138$ Rounded on 150 members.

\section{STATISTICAL TOOL USED}

The statistical tools are used for analyzing the data are:

1) PERCENTAGE ANALYSIS

2) COMPARATIVE ANALYSIS

3) TREND ANALYSIS

\section{RESEARCH APPROACH}

The study employee personally approached the participants with sequentially ordered issues that were well prepared. The questionnaire is ready based on the study's goals. For study purposes, direct agreement is used, staff immediately to gather information. The majority of data collected by the researcher are primary data collected through a

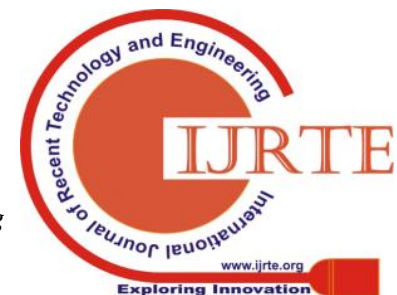


personal interview, where the researcher and the respondent operate face to face $[32,33]$.

TABLE 1: REDUCED STRESS AMONG YOUR SELF

\begin{tabular}{|l|l|l|}
\hline Particulars & Respondents & Percentage (\%) \\
\hline Difficult & 45 & 30 \\
\hline No chance & 35 & 23 \\
\hline Rarely & 25 & 17 \\
\hline Mostly & 41 & 27 \\
\hline No & 4 & 3 \\
\hline Total & $\mathbf{1 5 0}$ & $\mathbf{1 0 0}$ \\
\hline
\end{tabular}

\section{CHART 1 REDUCED STRESS AMONG YOUR SELF}

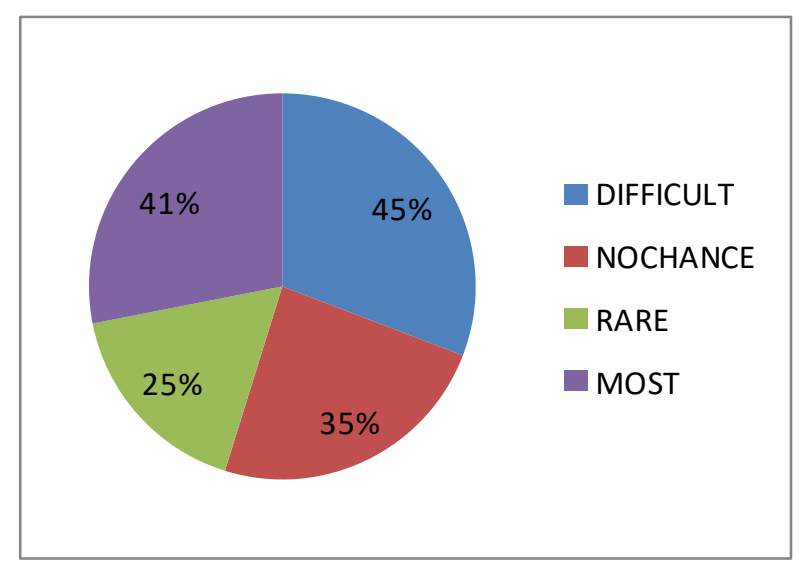

\section{INFERANCE:}

From the above table of maximum of respondents on $45 \%$ of difficult stress reduced among you self and the minimum of respondents on $4 \%$ of no particulars the remaining of respondents on $41 \%$ of most and $35 \%$ respondents of no change the only one remain respondents on $25 \%$ of rare system of stress reduced among you self.

\section{TABLE 2 STRESS IN WORKING AREA}

\begin{tabular}{|l|l|l|}
\hline Particulars & Respondents & Percentage (\%) \\
\hline More & 10 & 7 \\
\hline Less & 40 & 27 \\
\hline Neutral & 40 & 27 \\
\hline Sometimes & 45 & 30 \\
\hline Fulltime & 15 & 9 \\
\hline Total & $\mathbf{1 5 0}$ & $\mathbf{1 0 0}$ \\
\hline
\end{tabular}

\section{CHART 2: STRESS IN WORKING AREA}

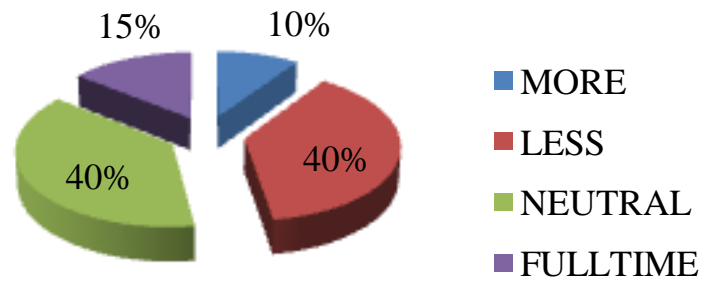

INFERENCE:

Based on the table isinferred the majority of respondents on $45 \%$ of sometimes and the minority of the respondents on $10 \%$ of more and the remaining respondents on $40 \%$ two particulars of less and neutral the final respondents on $15 \%$ respondents of fulltime feel about stress in working area.

TABLE 3 ORGANIZATION SUPPORT

\begin{tabular}{|l|l|l|}
\hline PARTICULARS & RESPONDENTS & $\begin{array}{l}\text { PERCENTAGE } \\
(\boldsymbol{\%})\end{array}$ \\
\hline ALWAYS & 8 & 5 \\
\hline SOMETIMES & 32 & 22 \\
\hline NEVER & 50 & 33 \\
\hline RARE & 45 & 30 \\
\hline NOTALL & 15 & 10 \\
\hline TOTAL & $\mathbf{1 5 0}$ & $\mathbf{1 0 0}$ \\
\hline
\end{tabular}

\section{CHART 3 ORGANIZATION SUPPORT}

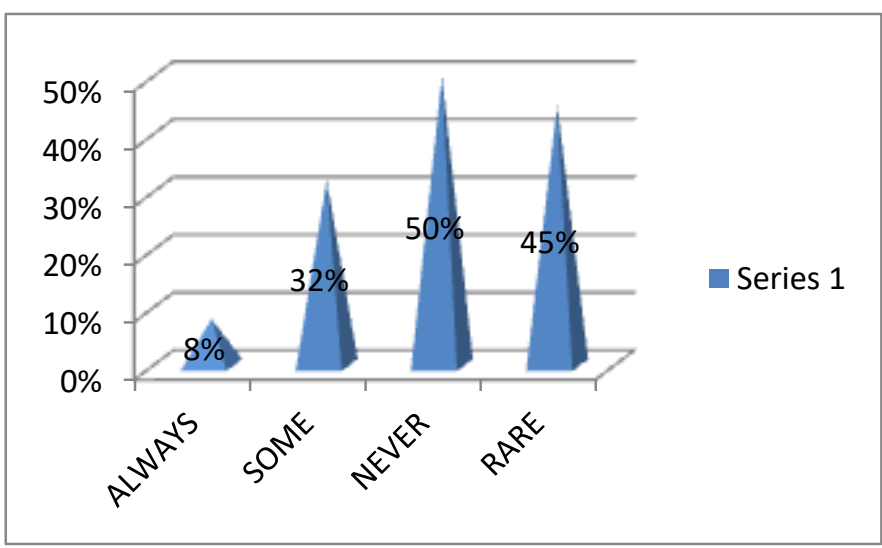

\section{INFERANCE:}

From the table of majority of the respondents on $50 \%$ of never in the organization support to the employers and the minority of respondents on $8 \%$ of always support to the organization in employers the remaining respondents on $45 \%$ of rare case and $32 \%$ of

\section{Published By:}


respondents on sometimes support to the organization.

\section{TABLE 4.9 STRESS OUTSIDE ORGANIZATION}

\begin{tabular}{|l|l|l|}
\hline Particulars & Respondents & $\begin{array}{l}\text { Percentage } \\
(\%)\end{array}$ \\
\hline Always & 18 & 13 \\
\hline No & 67 & 45 \\
\hline Rarely & 52 & 30 \\
\hline Sometimes & 13 & 7 \\
\hline Situation & 3 & 5 \\
\hline Total & $\mathbf{1 5 0}$ & $\mathbf{1 0 0}$ \\
\hline
\end{tabular}

\section{CHART 4 STRESS OUTSIDE ORGANOZATION}

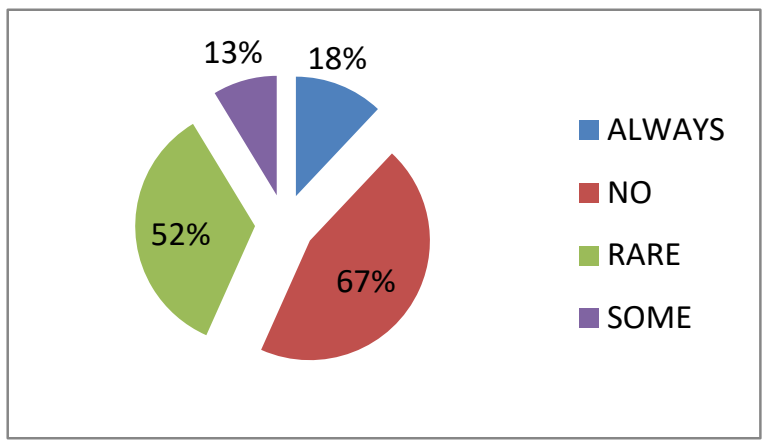

\section{INFERANCE:}

Based on the table is inferred of the maximum of respondents on $67 \%$ of no stress in outside of the organization and the minimum of respondents on $3 \%$ of situation based of stress in outside of the organization the remaining respondents on $52 \%$ of rarely case on and the $18 \%$ respondents of always facing the stress in outside of the organization

\section{RESUlts}

\section{CHI- SQUARE TEST}

AIM:

Ho: There is significance difference between years of experience and stress relief program.

H1: There is no significance difference between years of experience and stress relief program.

POOLING METHOD:

\begin{tabular}{|l|l|l|l|l|}
\hline $\mathbf{Q}$ & $\mathbf{E}$ & $(\mathbf{O - E})$ & $(\mathbf{O - E}) 2$ & $(\mathbf{O - E}) 2 / \mathbf{E}$ \\
\hline 19 & 11 & 8 & 64 & 5.8 \\
\hline 39 & 47 & -8 & 64 & 1.36 \\
\hline 21 & 30 & -9 & 81 & 2.7 \\
\hline 11 & 9 & 2 & 4 & 0.44 \\
\hline 10 & 3 & 7 & 49 & 6.33 \\
\hline & & & TOTAL & 16.63 \\
\hline
\end{tabular}

FORMULA:

$\mathrm{X}^{2}=\sum(\mathrm{O}-\mathrm{E})^{2 / \mathrm{E}}$
Expected frequency $=$ row total - column total $/$ grand total Degree of freedom $=(n-1)=(5-1)=4$.

Calculated value $=16.63$

Table value $=(9.488)($ At $5 \%$ level of significance $)$ $\mathrm{CV}>\mathrm{TV}$

16.63>9.488Rejected H0.

It is accepted that there is significance difference between year of experience and stress relief program.

\section{CORRELATION CO-EFFICIENT}

To correlate the relationship between the duration of job satisfaction and the salary satisfaction of mother son private limited

\begin{tabular}{|c|c|c|c|c|}
\hline $\mathbf{X}$ & $\mathbf{Y}$ & $\mathrm{X} 2$ & Y2 & $\mathbf{X Y}$ \\
\hline 19 & 18 & 361 & 324 & 342 \\
\hline 35 & 51 & 1225 & 2601 & 1785 \\
\hline 48 & 43 & 2304 & 1849 & 2064 \\
\hline 26 & 22 & 676 & 484 & 572 \\
\hline 22 & 16 & 484 & 256 & 352 \\
\hline $\begin{array}{l}\mathrm{EX}=15 \\
0\end{array}$ & $\begin{array}{l}E Y=15 \\
0\end{array}$ & $\begin{array}{l}\text { EX2 }=505 \\
0\end{array}$ & $\begin{array}{l}\text { EY2=551 } \\
4\end{array}$ & $\begin{array}{l}E X Y=511 \\
5\end{array}$ \\
\hline
\end{tabular}

\section{$\mathrm{R}=\mathrm{NEXY}-\mathrm{EXEY} \wedge(\mathrm{NEX} 2-\mathrm{EX} 2) \backslash(\mathrm{NEY} 2-\mathrm{EY} 2)$}

$\mathrm{R}=4.318$

The correlation co-efficient 4.318 the relationship between the duration of job satisfaction and the salary satisfaction of MOTHER SON RIVATE LIMITED.

\section{DISCUSSION}

- Most of the respondents are always to the category of 3-6 year experience of the organization.

- Majority of the respondents oftheworking field.

- Maximum of the respondents of working for 9 to 10 in the company.

- Most of the respondents of neutral agree that the management conducting stress relief program.

- Majority of the respondentsoffacing problem rarely on your organization.

- Maximum of the respondents of stress relief about your needs on difficulties.

- Most of the respondents of sometimes of stress in working area.

- Most of the respondents of never on organization support.

- Majority of the respondents on of say no that the stress on outside of the organization.

- The maximum of therespondentsofsatisfaction the salary package.

- The most of the respondents of the uncomfortable the performance disturbance.

- Most of the respondents of sometime of time balance of the employee life balance.

- The Majority of the respondents of sometimes of time management. 
- The maximum of the respondents on of stress on target stress.

- Most of the respondents of daily on stress relief events.

- The majority of the respondents of may be on life balance.

- Majority of the respondents of never stress effect by the organization.

- Most of the respondents of not all on stress on organization.

- To find out the difference between years of experience and working hours by using chi square test.

- To find out the relationship between job satisfaction and salary satisfaction by using rank correlation co efficient.

\section{SUGGESTIONS}

- From the study, it is recommended that the company has to decrease the working hour of the employees to reduce the worker's stress

- Counseling to the workers will reduce their stress.

- The superiors should see that they don't give more work load to workers.

- Organization to conducting the stress relief program in years only.

- Employees try to reduce the stress in among your ownself.

- Organization to follow the government rules and regulation about employee welfare.

- Basic infrastructure available in working area and also available in safety.

- Organization thing about employee health and change the working environment.

- The employee working time period provides on below 9 hours.

- Every one six month to conducting the employee stress relief program.

- Employee should be satisfaction on job and salary packaging systems.

- Organization to be reduced the working pressure to the employee.

- Organization any time should be motivation of employee on award and reward system.

- Organization should be supported on employee in corrected way.

- The organization to be provided the travel facilities of employee to reduce the time management stress to the employee.

\section{CONCLUSION}

The project work done in MOTHORSON PVT LTD, CHENNAI has given immense knowledge about stress management $\&$ its impact on the employees.

The period spent on the survey was useful one and came to know about various factors involved in stress inside the organization. The company has to take adequate steps to make their employees stress free.

Respondents agree that the management is taking measures to reduce the stress of the workers. The respondents rarely fight with their co - employees when they are in stress. The respondents feel that they have enough time to perform without any disturbance.

They are to be given the opportunity to learning something about the stress management and to get best experienced and knowledge and to develop my skills to really thank the organization.

\section{REFERENCES}

[1] BharthVajan R., Ramachandran S.,Psychographic dimensions of training,2016,International Journal of Pharmacy and Technology,V-8,I-4,P-23727-23729

[2] Balakrishnan P., Bharthvajan R.,A study on human resource planning in hospitals in Chennai City,2014,International Journal of Applied Engineering Research,V-9,I-22,P-7503-7507

[3] Priyadarsini P., Bharthvajan R.,Role of emotional intelligence training programme in reducing the stress of the nurses,2014,International Journal of Applied Engineering Research,V-9,I-22,P-7411-7421

[4] Kerinab Beenu G., Bharthvajan R.,Empirical analysis on the cosmetic buying behavior of young women in South India,2014,International Journal of Applied Engineering Research,V-9,I-22,P-7361-7366

[5] Balakrishnan P., Bharthvajan R.,Whistling in the wind,2014,International Journal of Applied Engineering Research,V-9,I-22,P-7586-7593

[6] Krishnan B., Peter M.,Health hazards of Indian Bpo employee-an alarming issue,2014,International Journal of Applied Engineering Research,V-9,I-22,P-7336-7341

[7] Kerinab Beenu G.H., Peter M.,Role of insurance in economic development,2014,International Journal of Applied Engineering Research,V-9,I-22,P-7532-7539

[8] Balakrishnan P., Peter M., Priyadarsini P.,Efficiency of safety measures for wellbeing of employees in manufacturing industry,2014,International Journal of Applied Engineering Research,V-9,I-22,P-7376-7382

[9] Anbarasi M., Praveen Kumar S.,Online sales promotions of herbal products and its effectiveness towards tanisha.com,2019,Indian Journal of Public Health Research and Development,V-10,I-1,P-195-200

[10] Anbarasi M., Praveen Kumar S.,Various online marketing and promotions strategies to improve the validation towards the organic products in the pharmaceutical sectors,2019,Indian Journal of Public Health Research and Development,V-10,I-1,P-263-269

[11] Loganathan R., Praveen Kumar S.,Grievance handling a key factor for solving issues of employees in an organization,2014,International Journal of Applied Engineering Research,V-9,I-22,P-7483-7491

[12] Loganathan R., Praveen Kumar S.,Study on preference of private label brands in super and Hypermarkets, 2014,International Journal of Applied Engineering Research,V-9,I-22,P-7327-7335

[13] Smitha M., Praveen Kumar S.,Understanding stress and its managementamong the nurses in Chennai city,2014,International Journal of Applied Engineering Research,V-9,I-22,P-7560-7565

[14] Kerinab Beenu G.H., Praveen Kumar S.,A study on the investment behavior of Chennai investors in mutual fund schemes,2014,International Journal of Applied Engineering Research,V-9,I-22,P-7520-7525

[15] Loganathan R., Praveen Kumar S.,Retention strategies key for organizational productivity,2014,International Journal of Applied Engineering Research,V-9,I-22,P-7443-7447

[16] Pavithra J., Ganesan M., Brindha G.,State wise analysis of microfinance sector in India,2016,International Journal of Pharmacy and Technology,V-8,I-4,P-23417-23432

[17] Pavithra J., Ganesan M.,A comparative study on microfinance in India and abroad,2016,International Journal of Applied Business and Economic Research,V-14,I-8,P-5471-5476

[18] Pavithra J., Ganesan M.,A study on awareness and impact of micro-financial schemes,2016,International Journal of Applied Business and Economic Research,V-14,I-8,P-5449-5460

[19] Senthilmurugan P., Pavithra J.,Consumer preference towards organised retailing with reference to Big Bazaar,2014,International Journal of Applied Engineering Research,V-9,I-22,P-7469-7475

[20] Senthilmurugan P., Pavithra J.,Implication of social media marketing in growing healthcare industry,2014,International Journal of Applied Engineering Research,V-9,I-22,P-7448-7456

[21] Loganathan R., Pavithra J.,Consumer perception towards private label brand over other brands in super markets and hypermarkets,2014,International Journal of Applied Engineering Research,V-9,I-22,P-7355-7360

[22] Kerinab Beenu G., Pavithra J.,Tradeâ€"off between liquidity and profitability in logistics industry,2014,International Journal of Applied Engineering Research,V-9,I-22,P-7398-7401 
[23] Kerinab Beenu G., Pavithra J.,A study on the prospective consumerâ€ $€^{\mathrm{TM}_{S}}$ perception towards utility cars in Chennai city,2014,International Journal of Applied Engineering Research,V-9,I-22,P-7526-7531

[24] Pavithra J., Dilli Babu P., Ambuli T.V.,A study on budgetary control at Maruti Service Masters, Chennai,2014,International Journal of Applied Business and Economic Research,V-12,I-2,P-151-161

[25] Pavithra J., Dilli Babu P., Ambuli T.V.,A study on customer satisfaction of retro Garments Pvt Ltd, Chennai,2014,International Journal of Applied Business and Economic Research,V-12,I-2,P-381-391

[26] Kerinab Beenu G.H., Pavithra J., Senthilmurugan P.,A study on the influence of promotional activities for TATA ARIA among consumers in Chennai,2014,International Journal of Applied Engineering Research,V-9,I-22,P-7572-7578

[27] Vijayaragavan S.P.,An investigative expert that's general FBG sensors,International Journal of Mechanical Engineering and Technology,V-8,I-8,PP-1500-1505,Y-2017

[28] Vijayaragavan S.P.,Equalization routing protocol for Wi-Fi sensor strategy,International Journal of Mechanical Engineering and Technology,V-8,I-8,PP-1662-1666,Y-2017

[29] Karthik B., Kiran Kumar T.V.U., Vijayaragavan P., Bharath Kumaran E.,Design of a digital PLL using 0.35 $\hat{\mathrm{I}}^{1 / 4 \mathrm{~m}}$ CMOS technology,Middle East Journal of Scientific Research,V-18,I-12,PP-1803-1806,Y-2013

[30] Kanniga E., Selvaramarathnam K., Sundararajan M.,Kandigital bike operating system,Middle - East Journal of Scientific Research, V

[31] Jasmin M., Vigneshwaran T., Beulah Hemalatha S.,Design of power aware on chip embedded memory based FSM encoding in FPGA,International Journal of Applied Engineering Research,V-10,I-2,PP-4487-4496,Y-2015

[32] Jasmin M.,Optimization techniques for low power VLSI circuits,Middle East Journal of Scientific Research,V-20,I-9,PP-1082-1087,Y-2014

[33] Jasmin M., Vigneswaran T.,Fuzzy controller for error control of on - Chip communication,2017 International Conference on Algorithms, Methodology, Models and Applications in Emerging Technologies, ICAMMAET 2017,V-2017-January,I-,PP-1-5,Y-2017

\section{AUTHORS PROFILE}

Magdalene Peter, Associate Professor, Department of Management Studies, Bharath Institute of Higher Education and Research, Chennai, India

S. Fabiyola Kavitha, Associate Professor, Department of Management Studies, Bharath Institute of Higher Education and Research, Chennai, India

R. K. Renju, Student, Department of Management Studies, Bharath Institute of Higher Education and Research, Chennai, India 